\title{
Increased Renal Proximal Convoluted Tubule Transport Contributes to Hypertension in Cyp4a14 Knockout Mice
}

\author{
Raymond Quigley $^{a}$ Sumana Chakravarty ${ }^{a, f}$ Xueying Zhao ${ }^{b}$ John D. Imig ${ }^{\text {b, c }}$ \\ Jorge H. Capdevilad, e \\ ${ }^{a}$ Department of Pediatrics, University of Texas Southwestern Medical Center at Dallas, Dallas, Tex., \\ ${ }^{b}$ Vascular Biology Center and 'Department of Physiology, Medical College of Georgia, Augusta, Ga., \\ Departments of ${ }^{\mathrm{d}}$ Medicine and ${ }^{\mathrm{e}}$ Biochemistry, Vanderbilt University Medical School, Nashville, Tenn., USA; \\ ${ }^{f}$ Indian Institute of Chemical Technology (IICT), Tarnaka, Hyderabad, India
}

\section{Key Words}

In vitro microperfusion - Proximal tubule transport .

Eicosanoids

\begin{abstract}
Background/Aims: Disrupting the enzyme Cyp4a14 in mice leads to hypertension, which is more severe in the male mice and appears to be due to androgen excess. Because the Cyp4a14 enzyme is located in the proximal tubule of the kidney, we hypothesized that there could be dysregulation of transport in this segment that could contribute to the hypertension. Methods: Wild-type (SV/129) mice and mice that had targeted disruption of the Cyp4a14 gene were studied. Proximal convoluted tubules (PCT) from knockout and wildtype mice were dissected and perfused in vitro for measurement of volume absorption $\left(J_{\mathrm{V}}\right)$. Expression of the sodiumhydrogen exchanger 3 (NHE3), the predominant transporter responsible for sodium transport in this segment, was measured by immunoblot. Renal vascular (afferent arteriole) responses to angiotensin and endothelin were also measured. Results: PCT volume absorption was elevated in tubules from the Cyp4a14 knockout mice as compared to the wild-
\end{abstract}

type mice. Brush border membrane NHE3 expression was almost 2-fold higher in Cyp4a14 knockout mice than in wildtype mice. No difference was found in the afferent arteriolar response. Conclusion: Thus, hypertension in the Cyp4a14 knockout mice appears to be driven by excessive fluid reabsorption in the proximal tubule, which is secondary to overexpression of NHE3.

Copyright $\odot 2009$ S. Karger AG, Basel

\section{Introduction}

Although hypertension remains a major clinical problem, the pathophysiologic cause in most cases is unknown. Gender differences in the incidence and severity of hypertension suggest the involvement of sex-dependent mechanisms in the pathogenesis of human hypertension $[1,2]$. Animal models of hypertension also demonstrate a gender difference in the severity and end-organ response to hypertension $[3,4]$.

Recently, disruption of the Cyp4a14 gene in mice was shown to cause hypertension that was more severe in male mice [5]. The male mice had elevated concentrations of androgens in their blood and castration corrected the

\section{KARGER}

๑) 2009 S. Karger AG, Basel

Fax +41613061234 E-Mail karger@karger.ch www.karger.com www.karger.com/nep
Raymond Quigley, MD

Department of Pediatrics, UT Southwestern Medical Center

5323 Harry Hines Blvd., Dallas, TX 75235-9063 (USA)

Tel. +1 214648 3438, Fax +1 2146482034

E-Mail raymond.quigley@utsouthwestern.edu 
blood pressure in the hypertensive male mice. Replacement of androgens to the castrated mice once again led to hypertension [5]. Thus, this appeared to be a good model of gender difference in hypertension.

We also recently examined the effects of androgens on blood pressure and renal function in male SpragueDawley rats [6]. Administration of dihydrotestosterone (DHT) to normal male rats was shown to stimulate proximal tubule transport [6]. The mechanism appeared to involve the intrarenal renin-angiotensin system and upregulation of the sodium-hydrogen exchanger 3 (NHE3) [6]. Thus, androgens appear to have a direct effect to upregulate sodium reabsorption in the proximal tubule and have an impact on blood pressure regulation.

The distribution of Cyp4a14 in the mouse nephron is principally in the proximal tubule [7]. The effects of eicosanoids on transport in the proximal tubule have been studied using in vitro microperfusion of rabbit proximal straight tubules [8]. The results demonstrate that 20-hydroxyeicosatetraenoic acid (HETE) inhibited transport and 19-S HETE stimulated transport. However, it remains unknown how this would affect overall sodium balance and blood pressure control in the intact animal.

The purpose of the present study was to directly examine proximal tubule transport in the Cyp4a14 knockout (KO) mice as well as NHE3 expression. This was done using in vitro microperfusion of proximal convoluted tubules from wild-type control and Cyp4a14 KO mice. In addition, we also examined vascular reactivity of the afferent arteriole in the kidney to determine if there were altered responses to vasoactive peptides.

\section{Methods}

Cyp4a14 KO Mice

The Cyp4a14 gene disruption model has been previously developed and reported [5]. These served as the experimental model. Wild-type SV/129 mice served as the controls.

\section{Blood Pressure Measurement}

The arterial blood pressure of conscious 12- to 14-week old male mice were measured by means of a right carotid artery catheter (300-500 $\mu \mathrm{m}$ outer diameter). After surgery (24-48 h), the animals were allowed to become familiar with their environment and, after stabilization, their arterial blood pressures were monitored continuously for at least $30 \mathrm{~min}$ by using a pressure transducer as previously described from our laboratory [5]. The animals were maintained on either a standard mouse chow $(0.3 \%$ salt $)$, low-salt diet $(0.03 \%$ salt $)$ or high salt diet $(8 \%)$ for approximately 3 weeks.
In vitro Tubule Microperfusion

Proximal convoluted tubules from Cyp4a14 KO and wild-type mice (SV/129) were perfused in vitro as previously described [911]. Briefly, tubules were dissected in cooled $\left(4^{\circ} \mathrm{C}\right)$ modified Hank's solution containing in $\mathrm{mM}$ : $137 \mathrm{NaCl}, 5 \mathrm{KCl}, 0.8 \mathrm{MgSO}_{4}$, $0.33 \mathrm{Na}_{2} \mathrm{HPO}_{4}, 0.44 \mathrm{KH}_{2} \mathrm{PO}_{4}, 1 \mathrm{MgCl}_{2}, 10$ Tris- $\mathrm{HCl}, 0.25 \mathrm{CaCl}_{2}$, 2 glutamine and $2 \mathrm{~L}$-lactate. This solution was bubbled with $100 \%$ $\mathrm{O}_{2}$ and had a $\mathrm{pH}$ of 7.4. Tubules were then transferred to a $1.2 \mathrm{ml}$ thermostatically-controlled $\left(38^{\circ} \mathrm{C}\right)$ bathing chamber and perfused with concentric glass pipettes. The perfusion solution contained in mM: $115 \mathrm{NaCl}, 25 \mathrm{NaHCO}_{3}, 2.3 \mathrm{Na}_{2} \mathrm{HPO}_{4}, 10 \mathrm{Na}$ acetate, $1.8 \mathrm{CaCl}_{2}, 1 \mathrm{MgSO}_{4}, 5 \mathrm{KCl}, 8.3$ glucose and 5 alanine and had an osmolality of $290 \mathrm{mOsm} / \mathrm{kg}$ water. The bathing solution was designed to simulate plasma and contained in mM: $115 \mathrm{NaCl}, 25$ $\mathrm{NaHCO}_{3}, 2.3 \mathrm{Na}_{2} \mathrm{HPO}_{4}, 10 \mathrm{Na}$ acetate, $1.8 \mathrm{CaCl}_{2}, 1 \mathrm{MgSO}_{4}, 5 \mathrm{KCl}$, 8.3 glucose and 5 alanine and also $6 \mathrm{gm} / \mathrm{dl}$ of albumin. The osmolality of the bathing solution was $290 \mathrm{mOsm} / \mathrm{kg}$ water. The perfusion and bathing solutions were bubbled with $95 \% \mathrm{O}_{2}$ and $5 \% \mathrm{CO}_{2}$ at $37^{\circ} \mathrm{C}$ and had a $\mathrm{pH}$ of 7.4. The osmolalities of the perfusion and bathing solutions were measured with a Wide Range Osmometer (Advanced Instruments, Model WDW, Norwood, Mass., USA) and adjusted to the desired osmolality by the addition of water or $\mathrm{NaCl}$. The bathing solution was exchanged at a rate of $0.5 \mathrm{ml} / \mathrm{min}$ to keep the osmolality and $\mathrm{pH}$ constant.

Volume absorption $\left(\mathrm{J}_{\mathrm{V}}\right.$; in $\left.\mathrm{nl} / \mathrm{min} \cdot \mathrm{mm}\right)$ was measured as the difference between the perfusion and collection rates and normalized per $\mathrm{mm}$ of tubule length. The collection rate was determined by timed collections using a constant volume pipette. Exhaustively dialyzed [methoxy- ${ }^{3} \mathrm{H}$ ] inulin (New England Nuclear, Boston, Mass., USA) was added to the perfusate at a concentration of $50 \mu \mathrm{Ci} / \mathrm{ml}$ so that the perfusion rate could be calculated. The tubule length was measured using an eyepiece micrometer.

\section{Brush Border Membrane Vesicle Preparation}

Animals were euthanized and kidneys were rapidly removed and immediately placed in ice-cold phosphate buffered saline (in mM: $137 \mathrm{NaCl}, 2.7 \mathrm{KCl}, 10.1 \mathrm{Na}_{2} \mathrm{HPO}_{4}, 1.7 \mathrm{KH}_{2} \mathrm{PO}_{4}, \mathrm{pH}$ 7.4). The capsule was removed and the cortex dissected, minced and placed in $15 \mathrm{ml}$ of an ice-cold isolation buffer (in mM: 300 mannitol, 16 HEPES, 5 EGTA, titrated to $\mathrm{pH} 7.4$ with Tris containing protease inhibitors aprotonin $(2 \mu \mathrm{g} / \mathrm{ml})$, leupeptin $(2 \mu \mathrm{g} / \mathrm{ml})$, and phenylmethylsulfonyl fluoride $(100 \mu \mathrm{g} / \mathrm{ml})$. The minced cortex was then homogenized with a Power Gen 125 (Fisher Scientific, Pittsburgh, Pa., USA) homogenizer at $4^{\circ} \mathrm{C}$. After addition of $230 \mu \mathrm{l}$ of $1.0 \mathrm{M}$ $\mathrm{MgCl}_{2}$ to precipitate cell debris, the homogenate was shaken vigorously for $10 \mathrm{~s}$, every $5 \mathrm{~min}$ for $20 \mathrm{~min}$, as previously described [12-14]. Subsequently, the homogenate was centrifuged at $2,500 \mathrm{~g}$ for $15 \mathrm{~min}$ at $4^{\circ} \mathrm{C}$. The supernatant was decanted, added to $230 \mu \mathrm{l}$ $1.0 \mathrm{M} \mathrm{MgCl}_{2}$, shaken vigorously for $10 \mathrm{~s}$ every $5 \mathrm{~min}$ for $20 \mathrm{~min}$, and centrifuged for $15 \mathrm{~min}$ at $2,500 \mathrm{~g}$ at $4^{\circ} \mathrm{C}$. The supernatant was then centrifuged at $48,400 \mathrm{~g}$ for $30 \mathrm{~min}$ at $4^{\circ} \mathrm{C}$. The pellets were resuspended in $1.5 \mathrm{ml}$ of ice-cold resuspension buffer $(5 \mathrm{mM}$ HEPES, pH 7.4; osmolality adjusted to $80 \mathrm{mOsm}$ with D-mannitol) using 22 and 25 gauge needles. Protein was determined in the crude homogenate and brush border membrane vesicles (BBMV) using a BCA protein assay (Pierce, Rockford, Ill., USA). Alkaline phosphatase activity was used to determine the enrichment as described previously [12-14]. 
Protein Abundance of $\mathrm{Na} / \mathrm{H}$ Exchanger (NHE3) in Brush

Border Membrane

BBMV protein was denatured and separated on a $7.5 \%$ polyacrylamide gel as previously described (50 $\mu \mathrm{g} /$ lane) [12-14]. The separated proteins within the gel were then transferred to polyvinylidone difluoride membrane overnight at $140 \mathrm{~mA}$ at $4^{\circ} \mathrm{C}$. The blot was blocked with Blotto (5\% nonfat milk, 0.05\% Tween 20, and $\mathrm{PBS}$ [pH 7.4]) for $1 \mathrm{~h}$, and then a primary antibody to rat NHE3 (gift from O. Moe, University of Texas Southwestern Med Center, Dallas, Tex., USA) was added at a 1:750 dilution and incubated for $2 \mathrm{~h}$ at room temperature on a shaker. $\beta$-Actin antibody (Sigma Chemical Co. St. Louis, Mo., USA) was added at a 1:15,000 dilution. The blot was washed with PBS containing $1 \%$ Tween, and then the secondary horseradish perioxidase-conjugated anti-rabbit immunoglobulin (for NHE3 antibody) and antimouse immunoglobulin (for $\beta$-actin antibody) were added at 1:10,000 dilution for $1 \mathrm{~h}$ in Blotto at room temperature. The blot was subsequently washed with PBS containing $1 \%$ Tween, and enhanced chemiluminescence was used to detect the bound horseradish perioxidase-conjugated antibody (Amersham Life Sciences, Inc., Arlington Heights, Ill., USA).

Afferent Arteriolar Response to Angiotensin II and Endothelin Experiments were performed on male wild-type SV129 mice and Cyp4a14 KO mice weighing an average of $29.5 \pm 0.81$ and $30.8 \pm 1.15 \mathrm{~g}$, respectively. Mice were anesthetized with a combination of thiobutabarbital (Inactin; $100 \mathrm{mg} / \mathrm{kg}$ i.p.) and ketamine (Ketaset; $10 \mathrm{mg} / \mathrm{kg}$ i.p.) and a midline abdominal incision was made. The right renal artery was cannulated via the superior mesenteric artery, and the kidney was immediately perfused with $\mathrm{Ty}$ rode's solution containing $6 \%$ albumin and a mixture of $\mathrm{L}$-amino acids [15]. All protocols were conducted in the juxtamedullary microvascular preparation perfused with the cell-free Tyrode's solution containing 6\% albumin. The Tyrode's solution was stirred continuously in a closed reservoir that was pressurized by a $95 \% \mathrm{O}_{2} / 5 \% \mathrm{CO}_{2}$ tank. The kidney was removed from the mouse and maintained in an organ chamber at room temperature throughout the isolation and dissection procedure. The juxtamedullary microvasculature was isolated for study as previously described [15]. The organ chamber was then warmed, and the tissue surface was continuously superfused with Tyrode's solution containing $1 \%$ albumin at $37^{\circ} \mathrm{C}$. Renal artery perfusion pressure, measured at the tip of the cannula, was set to $100 \mathrm{~mm} \mathrm{Hg}$.

Determination of afferent arteriolar diameter was accomplished using transillumination videomicroscopy as previously described [15]. The tissue was transilluminated and the focused image converted to a video signal by a high-resolution Newvicon camera. This video signal was electronically enhanced and recorded on videotape for later analysis. Afferent arteriolar inside diameters were measured at $15 \mathrm{~s}$ intervals using a digital image shearing monitor. The image shearing device is accurate to within $0.2 \%$ of the screen width or $0.2 \mu \mathrm{m}$ and measurement reproducibility is within $0.5 \mu \mathrm{m}$.

After a 20-min equilibration period, baseline diameter measurements of the afferent arteriole were made. Angiotensin II $(0.1-100 \mathrm{nM})$ or endothelin-1 (0.1-10 nM) was then administered in increasing concentrations and diameter changes monitored. Steady-state diameter was attained by the end of the second min and the average diameter of the third min of each treatment period was utilized for statistical analysis.

Increased PCT Transport in Cyp4a14 KO Mice

\section{Statistical Analysis}

Data are presented as mean \pm SEM. Comparisons between wild-type and Cyp4a14 KO mice were made by unpaired t tests. Differences in mean afferent arteriolar diameters between groups were evaluated with a 2-way analysis of variance (ANOVA) for repeated measures followed by Duncan's multiple range test. A $\mathrm{p}<0.05$ was considered statistically significant.

\section{Results}

\section{Blood Pressure}

Blood pressure was measured in the control $(n=5)$ and Cyp4a14 KO mice $(\mathrm{n}=5)$ on a regular sodium diet $(0.3 \%)$, low-sodium diet $(0.03 \%)$ and high-sodium diet (8\%). The mean arterial blood pressure of the Cyp4a14 KO mice was significantly higher than that of the wildtype controls on a regular diet $(0.3 \%$ sodium diet: wildtype $114 \pm 3$ mm Hg; Cyp4a14 KO $140 \pm 4$ mm Hg, p < 0.05). This is similar to the previously reported blood pressures in these animals [5].

To determine if the hypertension was salt sensitive, control $(n=5)$ and Cyp4a14 KO mice $(n=5)$ were placed on a low-sodium diet for 20-27 days. The sodium-restricted diet did not affect the blood pressure $(0.03 \%$ sodium diet: wild-type $114 \pm 3 \mathrm{~mm} \mathrm{Hg}$; Cyp4a14 KO $138 \pm 9 \mathrm{~mm} \mathrm{Hg}, \mathrm{p}<0.05)$. The blood pressures on the high-salt diet tended to increase for both groups, and were not statistically different. The blood pressure for the wild-type mice on the $8 \%$ salt diet was $130 \pm 10 \mathrm{~mm} \mathrm{Hg}$ and for the $\mathrm{KO}$ mice was $150 \pm 7 \mathrm{~mm} \mathrm{Hg}$ ( $\mathrm{p}=\mathrm{NS})$. Thus, the hypertension in the Cyp4a14 KO mice is not salt sensitive.

\section{Proximal Convoluted Tubule Transport}

The volume absorption rate of the proximal convoluted tubules (PCTs) from control and Cyp4a14 KO mice was determined by in vitro microperfusion. Figure 1 shows the volume absorption rates in PCTs from the Cyp4a14 KO and wild-type mice. As can be seen, the rate of transport is about 50\% higher in the Cyp4a14 KO mice $(p<0.05)$. The length of the perfused tubule segments was not different between the 2 groups (wild-type $1.1 \pm$ 0.1; Cyp4a14 KO $0.9 \pm 0.1, \mathrm{p}=\mathrm{NS}$ ). Thus, there was a significant increase in the volume absorption rate in the Cyp4a14 KO mice that could contribute to the development of hypertension.

\section{NHE3 Expression}

Most of the sodium transport in the proximal tubule is mediated by sodium proton exchange. The principal 


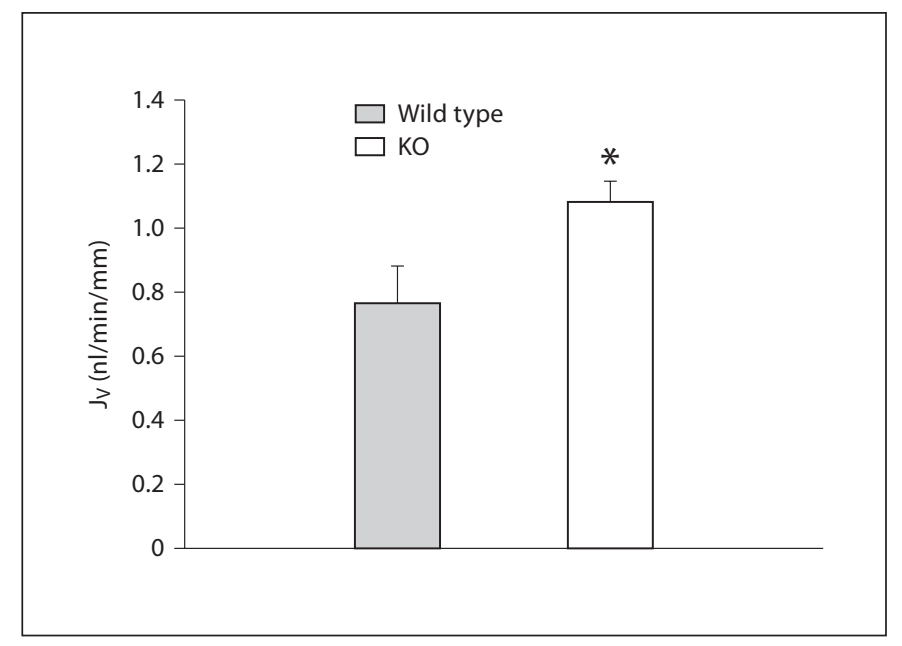

Fig. 1. The volume absorption rates of PCT from wild-type (SV/129) mice and Cyp4a14 KO mice. Volume absorption was significantly higher in the Cyp4a14 KO mice than in the wild-type control mice $\left({ }^{*} \mathrm{p}<0.05\right)$.

protein that performs this function is NHE3. We then determined the expression of NHE3 in the brush borders of proximal tubules from wild-type and Cyp4a14 KO mice using an immunoblot as previously used in our laboratory [6]. The antibody for NHE3 was a gift from Dr. Orson Moe and has been previously used in our laboratory [6].

Figure 2 shows the results of the Western blot for NHE3 and $\beta$-actin. Densitometry showed that the abundance of NHE3 was significantly higher in the samples obtained from the Cyp4a14 KO mice as compared to the wild-type controls. The expression of $\beta$-actin was not significantly different between the 2 groups. Thus, increased expression of NHE3 appears to be responsible for the increased volume absorption rate in the Cyp4a14 KO mice.

\section{Vascular Reactivity}

The last set of experiments was to determine if there was a component of increased vascular reactivity that would also contribute to the development of hypertension in the Cyp4a14 KO mice. Juxtaglomerular arterioles were examined and their response to administration of angiotensin II and to endothelin was measured. The results are shown in figure 3. As can be seen, there was no difference in the vascular reactivity in the response to either angiotensin II or endothelin. Thus, changes in vascular reactivity do not appear to contribute to the hypertension in the Cyp4a14 KO mice.



Fig. 2. Immunoblots of the brush border membrane NHE3 expression. The apical membranes of the proximal tubules from Cyp4a14 KO mice have a higher expression of NHE3 than the wild-type control mice.

\section{Discussion}

Hypertension remains a significant clinical problem. There are multiple causes of hypertension as well as numerous animal models of hypertension. We demonstrate in this study that the hypertension that develops in animals that have the Cyp4a14 gene disrupted is associated with increased volume transport in the proximal tubule. This, in turn, is due to upregulation of the expression of NHE3, the primary transporter in the proximal tubule responsible for sodium reabsorption.

Salt transport is critical to the maintenance of the extracellular fluid volume and hence of blood pressure. If the kidney does not reabsorb the large quantities of filtered sodium, the individual would quickly dehydrate. On the other hand, if salt transport is not regulated properly and there is too much reabsorption of sodium, the individual becomes volume expanded and hypertensive [16]. The known defects in this system affect sodium transport in the distal nephron, such as in Liddle's syndrome [17]. In this setting, salt restriction can correct the blood pressure problem since the collecting tubule is responsible for only 1 or $2 \%$ of the filtered load of sodium. It is not clear if a defect in sodium transport in the proximal tubule can be overcome by salt restriction. The proximal tubule must reabsorb more than $50 \%$ of the filtered load of sodium.

In the present model of hypertension, the Cyp4a14 KO mice had hypertension that was not salt sensitive. This would argue against a defect in transport in the distal nephron segments $[16,17]$. Because of our previous work with the effect of eicosanoids on proximal tubule function, we examined the transport rate of the proximal convoluted tubule in this animal model [8]. Volume absorption was found to be about $50 \%$ higher in the mice with 
Fig. 3. Vasoconstrictor response of the afferent arteriole to angiotensin II and endothelin. As can be seen, there was no difference in the vascular response to these 2 vasoconstrictors.

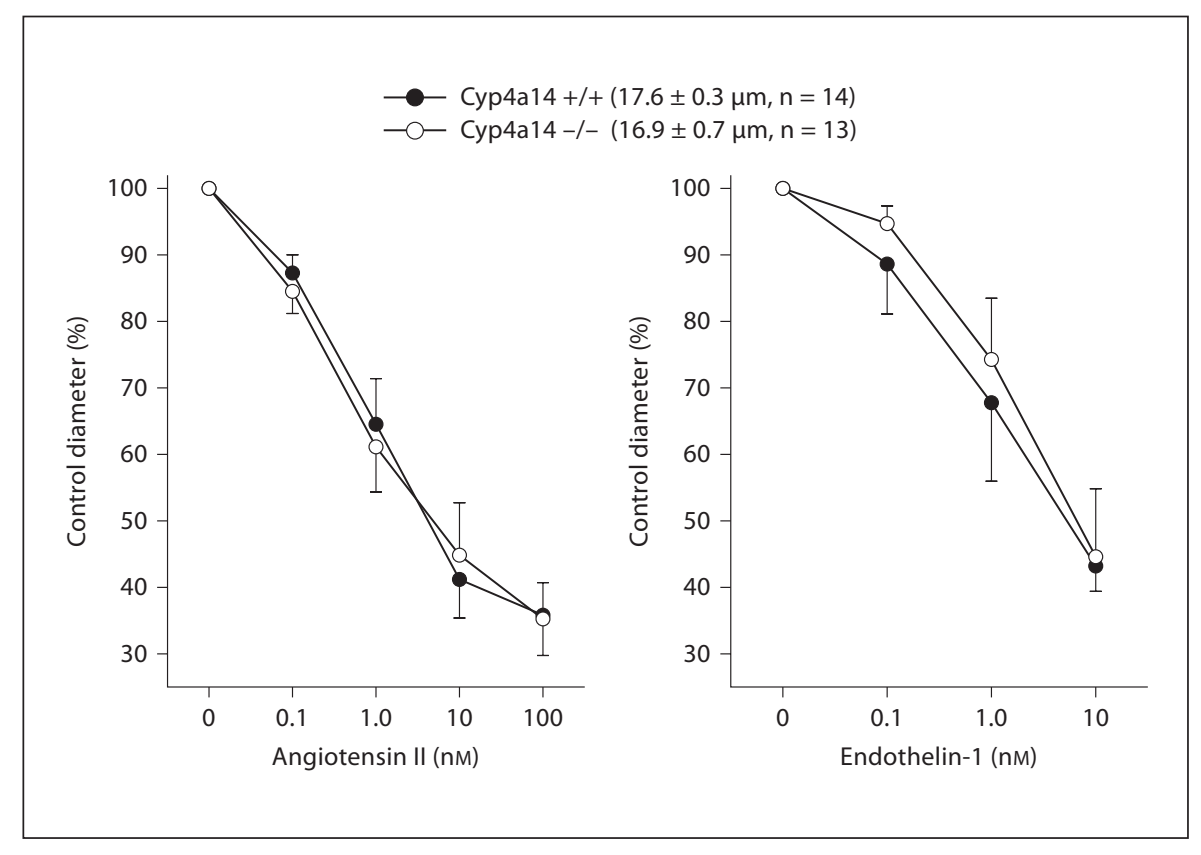

Cyp4a14 deletion. This appears to be a result of overexpression of NHE3.

We had previously examined the effects of androgens on proximal tubule transport and NHE3 expression in a rat model [6]. These animals received DHT injections for 10 days and were found to be hypertensive. In vivo microperfusion demonstrated that the proximal tubule transport was stimulated and there was evidence that the intrarenal renin-angiotensin system was responsible [6]. The expression of NHE3 in the brush border membranes from the rats that were treated with DHT was higher than that of the control rats. Our results in the Cyp4a14 KO mice are similar to these results, in that the NHE3 expression was higher in the KO mice and the volume absorption rate in the proximal tubule was found to be higher.

The vascular reactivity studies were very interesting and somewhat surprising. The initial report of hypertension in this mouse model showed that they had impaired afferent arteriolar autoregulatory capacity [5]. Previous studies have shown that eicosanoids participate in the autoregulation of the afferent arteriole [18]. Thus, the present findings of no difference in the reactivity of the afferent arteriole to angiotensin II and endothelin suggest that the effects are related to the androgens and not due to alterations in eicosanoid production.

Thus, sustained elevations in androgens as a result of Cyp4a14 gene disruption led to over expression of NHE3 in the proximal tubules. This in turn, caused a dysregula- tion of sodium transport in the proximal tubule as measured in the volume absorption rates. The increased sodium reabsorption likely contributed to the development of hypertension in this model.

\section{Acknowledgements}

This work was supported by National Institutes of Diabetes and Digestive and Kidney Diseases Grant DK 38226 (R.Q., J.I. and J.C.) and an American Heart Association Established Investigator Award to J.I. We wish to thank Laurel Johnson for her able secretarial assistance. Current E-Mail address for Dr. Chakravarty: sumanachak@iict.res.in.

\begin{tabular}{|c|c|}
\hline References & $\begin{array}{l}\text { Ostchega Y, Dillon CF, Hughes JP, Carroll M, } \\
\text { Yoon S: Trends in hypertension prevalence, } \\
\text { awareness, treatment, and control in older } \\
\text { U.S. adults: data from the National Health } \\
\text { and Nutrition Examination Survey } 1988 \text { to } \\
\text { 2004. J Am Geriatr Soc 2007;55:1056-1065. } \\
\text { Reckelhoff JF, Granger JP: Role of androgens } \\
\text { in mediating hypertension and renal injury. } \\
\text { Clin Exp Pharmacol Physiol 1999;26:127- } \\
\text { 131. } \\
\text { Reckelhoff JF, Zhang H, Srivastava K, Gran- } \\
\text { ger JP: Gender differences in hypertension in } \\
\text { spontaneously hypertensive rats: role of an- } \\
\text { drogens and androgen receptor. Hyperten- } \\
\text { sion 1999;34:920-923. }\end{array}$ \\
\hline
\end{tabular}

Nephron Physiol 2009;113:p23-p28 
4 Reckelhoff JF, Zhang H, Granger JP: Testosterone exacerbates hypertension and reduces pressure-natriuresis in male spontaneously hypertensive rats. Hypertension 1998;31: 435-439.

5 Holla VR, Adas F, Imig JD, Zhao X, Price E Jr, Olsen N, Kovacs WJ, Magnuson MA, Keeney DS, Breyer MD, Falck JR, Waterman $\mathrm{MR}$, Capdevila JH: Alterations in the regulation of androgen-sensitive Cyp 4a monooxygenases cause hypertension. Proc Natl Acad Sci USA 2001;98:5211-5216.

-6 Quan A, Chakravarty S, Chen JK, Chen JC, Loleh S, Saini N, Harris RC, Capdevila J, Quigley R: Androgens augment proximal tubule transport. Am J Physiol Renal Physiol 2004;287:F452-F459.

7 Stec DE, Flasch A, Roman RJ, White JA: Distribution of cytochrome P-450 4A and $4 \mathrm{~F}$ isoforms along the nephron in mice. Am J Physiol Renal Physiol 2003;284:F95-F102.

8 Quigley R, Baum M, Reddy KM, Griener JC, Falck JR: Effects of 20-HETE and 19(S)HETE on rabbit proximal straight tubule volume transport. Am J Physiol Renal Physiol 2000;278:F949-F953.
9 Burg M, Grantham J, Abramow M, Orloff J: Preparation and study of fragments of single rabbit nephrons. Am J Physiol 1966;210 1293-1298.

10 Quigley R, Baum M: Effects of growth hormone and insulin-like growth factor I on rabbit proximal convoluted tubule transport. J Clin Invest 1991;88:368-374.

11 Baum M, Loleh S, Saini N, Seikaly M, Dwarakanath V, Quigley R: Correction of proximal tubule phosphate transport defect in Hyp mice in vivo and in vitro with indomethacin Proc Natl Acad Sci USA 2003;100:1109811103.

12 Baum M, Dwarakanath V, Alpern RJ, Moe OW: Effects of thyroid hormone on the neonatal renal cortical $\mathrm{Na}+/ \mathrm{H}+$ antiporter. Kidney Int 1998;53:1254-1258.

13 Mulder J, Baum M, Quigley R: Diffusional water permeability (PDW) of adult and neonatal rabbit renal brush border membrane vesicles. J Membr Biol 2002;187:167-174.
4 Mulder J, Haddad MN, Vernon K, Baum M, Quigley R: Hypothyroidism increases osmotic water permeability (Pf) in the developing renal brush border membrane. Pediatr Res 2003; 53:1001-1007.

15 Imig JD, Deichmann PC: Afferent arteriolar responses to ANG II involve activation of PLA 2 and modulation by lipoxygenase and P-450 pathways. Am J Physiol 1997;273: F274-F282.

16 Schafer JA: 1993 Homer W. Smith Award. Salt and water homeostasis - is it just a matter of good bookkeeping? J Am Soc Nephrol 1994;4:1929-1950.

17 Garbers DL, Dubois SK: The molecular basis of hypertension. Annu Rev Biochem 1999; 68:127-155.

18 Imig JD, Pham BT, LeBlanc EA, Reddy KM, Falck JR, Inscho EW: Cytochrome P450 and cyclooxygenase metabolites contribute to the endothelin-1 afferent arteriolar vasoconstrictor and calcium responses. Hypertension 2000;35:307-312. 